\title{
Landslide Hazard Zonation from a GIS Perspective and Urban Planning Solutions in Central -Division of Fiji Islands
}

\author{
Joeli Varo, Tingneyuc Sekac, Sujoy Kumar Jana
}

\begin{abstract}
As is a characteristic of rainfall-induced surficial landslides, the mass movement occurred where the landform or configuration of the bedrock surface facilitated the concentration of slope water. More than half of the landslides originated in slope depressions or drainage lines, with initial failure taking place on an upper slope, ridge or summit. The present study aims at assessing the rainfall intensity, site-soil-geology and seismicity of the central division of Viti Levu, Fiji Islands using the GIS and remote sensing techniques. Rainfall intensity, Site-soilgeology, geomorphology and SRTM DEM data were the main sources of layers used to carry out such analysis using the Frequency Ratio methodology and ArcGIS Multi-Criteria Analysis (MCA). The final result of Land Slide Potential Zone (LSPZ) indicates the 'low', 'moderate' and 'high' zones. The result presents a readable map for people to simply identify their state of vulnerability within the study area. Thus, this research will assist professionals such as urban planners, engineers and legislators to implement sustainable developments whilst reducing the risks of disasters.
\end{abstract}

Key words: AUC curve; Frequency ratio; Landslide; MultiCriteria Analysis; Weighted sum

\section{INTRODUCTION}

The increase in intensity, severity and frequency of natural hazards has become a major global concern in the 21st century for Small Islands Developing States (SIDS)particularly in the South Pacific[1,2]. Fiji Islands consists of 322 islands, islets and atolls with an uneven distribution of 884,887 total population[3]. Fiji has a very complex tectonic history as it is located within the indoAustralian and the Pacific plate boundary juxtaposed in between two opposite facing subduction zones [4,5]. Due to this tectonic setting complexity, landslideshave become a lethal natural hazard to humanity which disaggregates their source of livelihoods, devastates flora and fauna, destroys built environment, loss of lives and negatively influence the welfare and wellbeing of society. Landslides are triggered by factors such as processes that bring forth the downslide of slope-forming materials including natural rocks, soils and trees as well as artificial fill, or a combination of both [5]. According to Greenbaum at al[6] the underlying principle is that relationships between past landsliding events, interpreted from remote sensing, and factors such as the geology, relief, soils andfaults provide the basis for

Revised Manuscript Received on September 14, 2019.

Joeli Varo, Department of Surveying and Land Studies, Papua New Guinea University of Technology, Lae 411, Morobe Province, Papua New Guinea.(Email: joelivaro@gmail.com)

Tingneyuc Sekac, Department of Surveying and Land Studies, Papua New Guinea University of Technology, Lae 411, Morobe Province, Papua New Guinea.(Email: tingneyucsekac@gmail.com)

Sujoy Kumar Jana, Corresponding Author, ORCID number:0000 0003-0901-5316, Department of Surveying and Land Studies, Papua New Guinea University of Technology, Lae 411, Morobe Province, Papua New Guinea.(Email: sujoy2007@gmail.com) modelling where future landslides are most likely to occur. There were several researches focused on different landslides zonation using different methodologies of analysis depending on the availability of data, knowledge of remote sensing and technology such as ArcGIS. In light of the work of Westen et al [7] the researcherincorporated the statistical method of GIS analysis to determine the zonation of landslide probability. These methods were deterministic, heuristic and statistical methodology for landslide zonation. Deng et al [8]developed a method to validate the frequency model by using the structural similarity approach in Pinggu District, Beijing in China. In Solaimani et al [9] and Lee and Pradhan [10] these researchers further integrated statistical methodology with logistic regression (LR) and frequency ratio (FR) in order to produce a landslide vulnerability map. Furthermore, Park et al. [11] have consolidated LR, FR, analytical hierarchy process (AHP)along with artificial neural network (ANN) models to produce and authorized the landslide susceptibility maps. Similarly, flood zonation was successfully accomplished in the South Pacific by Samanta et al [12]whereby remote sensing was integrated with frequency ratio to produce a flood hazard zonation of Markham river valley. Jana et al[13]used frequency ratio method to demarcate landslide susceptibility zones in the Busu catchment of Papua New Guinea. This study is essential because it adds knowledge and provide an understanding of the usefulness of ArcGIS and remote sensing analysis in Fiji Islands in solving complex issues of disaster risk reduction. Thus, several experts carried out research on landslide in Vitilevu Island, Fiji such Lawson [14], Howorth et al[15], Ram et al [16,19] and Greenbaum et al [17] revealed that rainfall - induced landslides are lethal for humanity.

Theaim of this research is to identify the landslide zones onCentral Division of Viti Levu Island. In order to accomplish this aim, the following three (3) strategical steps were implemented: (1) selection of bio-physical factors that determines landslides; (2) Analyzation of collected data using the Frequency Ratio (FR), Multi - Criteria Analysis (MCA) and advanced GIS environment; and (3) demarcation of landslides potential zones and recommend the physical and non-physical measures that can be implemented to reduce the risks of landslides. 


\section{STUDY AREA}

The study area inFigure 1below was selected due to the following reasons; 1.) it is on the leeward side of the country facing the south east trade winds associated with high rainfall, 2.) about 342,594 out of 884,887 Fiji's total poplation dwells within the study area alone which is equivalent to $38.7 \%$ of Fiji's total population, 3.) the study area comprises of the Fiji's rapidly developed capital city
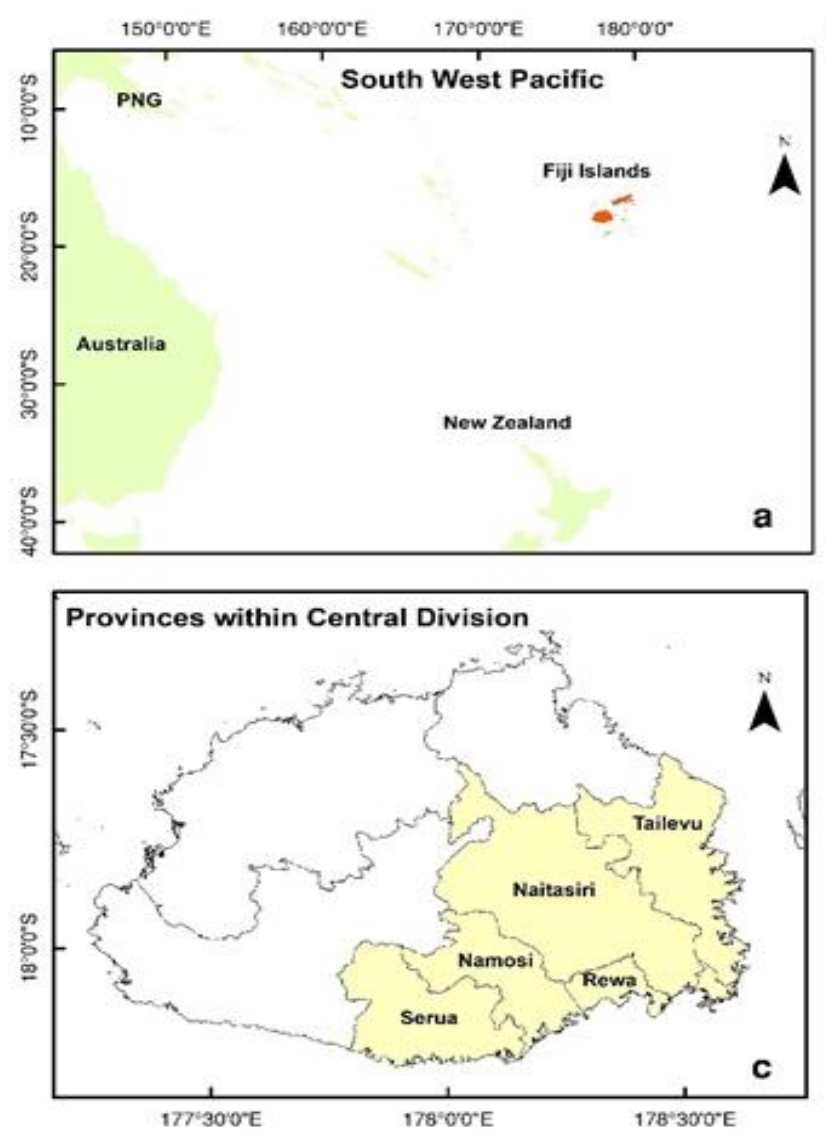

Figure 1. Locality maps, a Fiji and the main islands in the Southwest Pacific archipelagos, bCentral Division in Fiji Islands, cFive (5) Provinces within the Central Division, and dstudy area.

\section{MAPPING OF LANDSLIDE OCCURRENCE}

It is necessary to distinguish different types of landslide. A preliminary landslide study in Southeast Viti levu island by Lawson [14] revealed thefollowing three (3) classification of landslides as shown in Table 1 below;

Table 1. Landslide classification

\begin{tabular}{ll}
\hline Land slide classification & \multicolumn{1}{c}{ Description } \\
\hline \hline Slides & $\begin{array}{l}\text { Movement is along continuous shear or surface(s) within the } \\
\text { soil of rock substance or along existing defects. }\end{array}$ \\
Falls & $\begin{array}{l}\text { Soil or rock mass collapse along soil embarkment or cutting. } \\
\text { Movement is predominantly by tree fall and rolling. No sliding } \\
\text { surface form. }\end{array}$ \\
Flows & $\begin{array}{l}\text { Movement of soil or rock particle resembles that of viscous } \\
\text { fluid. Slip surfaces are destroyed by the moving mass. }\end{array}$ \\
\hline
\end{tabular}

Landslide inventory is fundamental information that needs to be acquired. It could either be acquired through high resolution satellite imagery or field survey using the
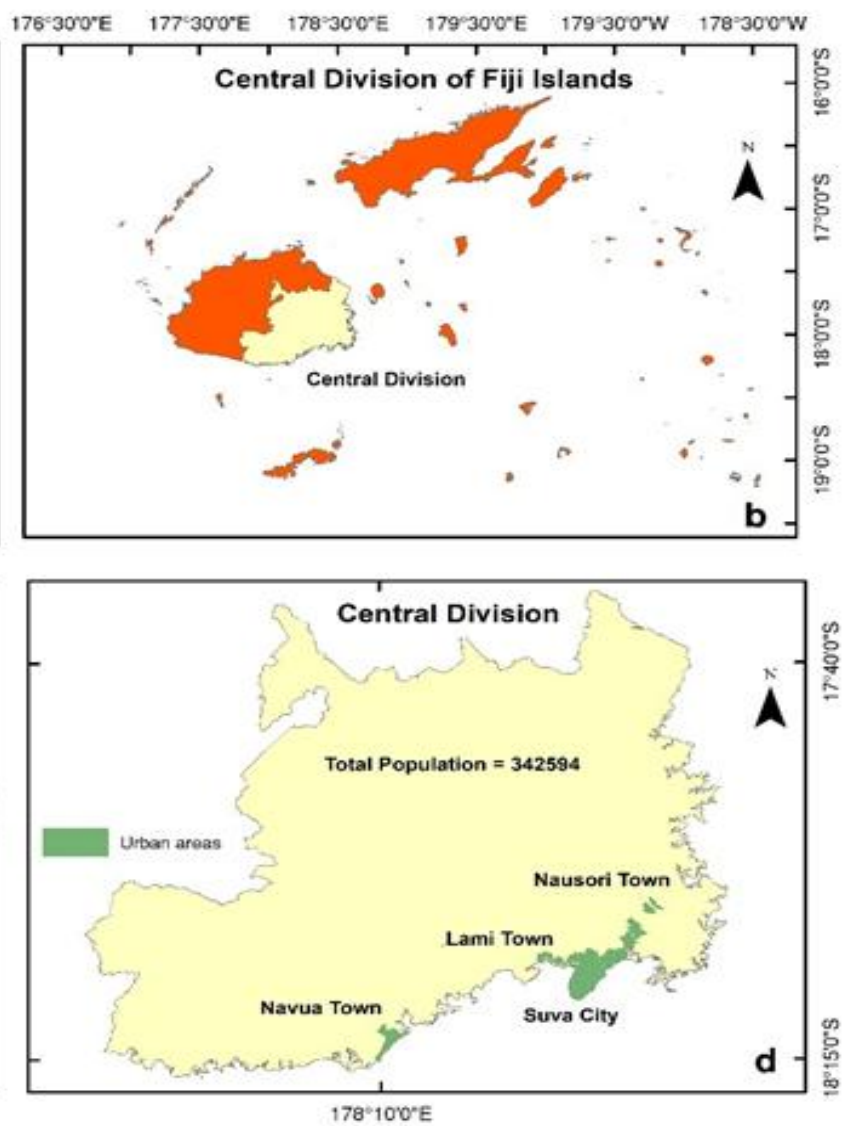

namely Suva and 4 towns, and 4.) major business operations, wharf, trades, services and residentialsare concentrated within the 3,980 Square kilometre of this study area[3].According to Varo et al [18] Fiji has a very complex tectonic history as it is located within the indo- Australian and the Pacific plate boundary juxtaposed in between two opposite facing subduction zones.

Geospatial Positional System (GPS) on the ground. For this present study, 35 points were collected on the ground as shown in Figure 2 below, high resolution Google satellite imagery was acquired and also referenced to the similar study that was once carried out by Greenbaum et al [6]with the assistance of the Fiji's Department of Mineral Resources. During field observation, it was evidenced that steeper slopes are vulnerable to landslides compare to gentle to flat land. Greenbaum et al [6] stated that slides involve the downslope movement of a rock, soil or debris mass occurring dominantly on surfaces of rupture or relatively thin zones of intense shear strain (slip, shear or failure surfaces) which may be curved or planar. Two main subdivisions can be recognised: rotational slides and translational slides. 


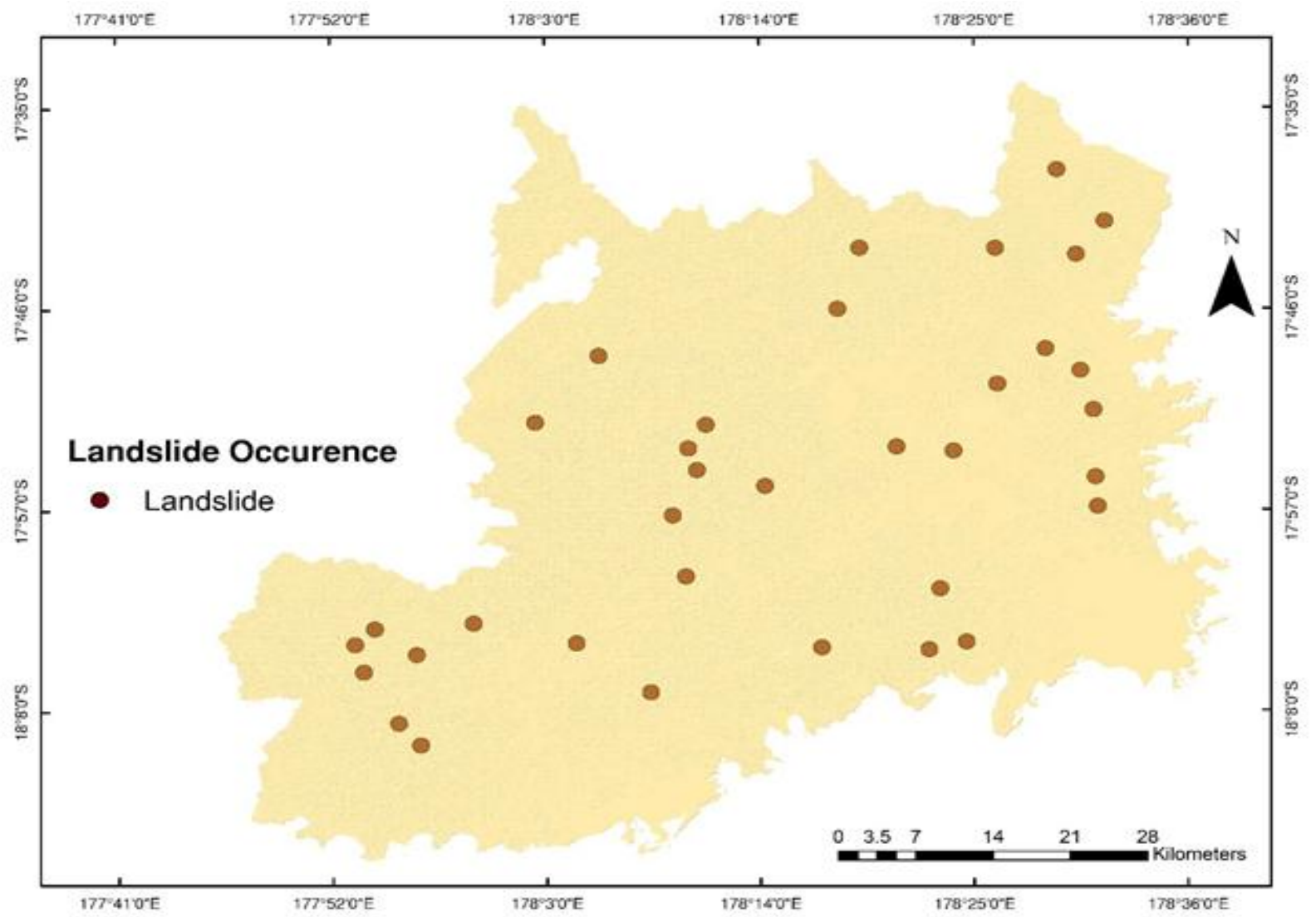

Figure 2. Major landslide occurrence in the Central Division.

Rainfall induced landslides is common in the study area due to the orientation of topography and the land compared to earthquake induced landslides.Howorth et al [15] looked at the coastal strip between Navua and Korovou. Their report gave a detailed account of the exceptionally high rainfall levels during the passage of cyclone Wally in a period of 1 - 5 April, 1960 as well as descriptions of the resulting devastation to the local population, property and road system. Peak water discharge rates measured near the mouths of the Navua and Rewa rivers apparently correlated with the triggering of landslides. The great majority of the slides involved only regolith material; in only one instance was the removal of bedrock observed.Ram et al [19] revealeda landslide pushed a bus with six people totheir deaths into the Wainibuka River along the King roads northeast of Korovou town.

\section{DATA PRE-PROCESSING AND METHODOLOGY}

Table 2illustrates the data collected and prepared for this particular study. The ArcGIS 10.5 software was used to convert fault lines and soil data into raster format. The monthly rainfall readingsfor year 2016 - 2018 recorded by the six (6)weather stations namely Navua, Laucala, Nasinu, RKS, Lomaivuna \& Nausori were derived from the Fiji Meteorological Department, the average annual readings for the three consecutive years were used accordingly. The interpolation technique was used for these six vector points to provide an average annual rainfall raster layer. The land use and geology vector layers weredigitized from the Fiji Mineral Resources Department Land Use and geology maps and re-confirmed with the Landsat 8 ETM satellite image (30 $\mathrm{m}$ spatial resolution), then it was converted to raster

format ready for further analysis. Slope layer was obtained from Fiji Mineral Resources Department for Vitilevu Island. All the data were converted to raster format using the spatial reference WGS 1972 datum for further ArcGIS analysis.

Table 2. Data source

\begin{tabular}{|c|c|c|}
\hline Data & Description & Source \\
\hline $\begin{array}{l}\text { Fault lines, Folding \& } \\
\text { Deep strike }\end{array}$ & $\begin{array}{l}\text { Derived from SPC. } \\
\text { Data source year: } 2018 .\end{array}$ & Fiji Mineral Department \\
\hline $\begin{array}{l}\text { Soil factors \& Soil } \\
\text { Attributes }\end{array}$ & $\begin{array}{l}\text { Derived from Fiji LUP } \\
\text { Guidelines. } \\
\text { Data source year: } 2015\end{array}$ & Fiji Ministry of Agriculture \\
\hline Rainfall factors & $\begin{array}{l}\text { Derived from Fiji Meteorology } \\
\text { Department } \\
\text { Data source year: } 2019\end{array}$ & $\begin{array}{l}\text { Fiji Meteorological } \\
\text { Department }\end{array}$ \\
\hline $\begin{array}{l}\text { Land Use/Zoning/Built } \\
\text { infrastructures }\end{array}$ & $\begin{array}{l}\text { Derived from Fiji Department } \\
\text { of Town \& Country Planning. } \\
\text { Data source year: } 2018\end{array}$ & $\begin{array}{l}\text { Fiji Department of Town and } \\
\text { Country Planning }\end{array}$ \\
\hline Slope & $\begin{array}{l}\text { Derived from SPC. } \\
\text { Data source year: } 2018\end{array}$ & Fiji Mineral Department \\
\hline $\begin{array}{l}\text { Landsat } 8 \text { ETM \& } \\
\text { satellite image }(30 \mathrm{~m} \\
\text { spatial resolution - 2017) }\end{array}$ & $\begin{array}{l}\text { Downloaded from } \\
\text { https://ibra.developmentseed.o } \\
\text { rg/ for verification purposes. } \\
\text { Data source year } 2019 .\end{array}$ & $\begin{array}{l}\text { PNG University of } \\
\text { Technology }\end{array}$ \\
\hline $\begin{array}{l}\text { Geology (rock type } \\
\text { classification) }\end{array}$ & $\begin{array}{l}\text { Derived from Fiji Geology } \\
\text { map. } \\
\text { Data source year: 1936, 1959, } \\
\text { 1990, 1994 \& 2015. }\end{array}$ & $\begin{array}{l}\text { Fiji Mineral Resources } \\
\text { Department \& PNG } \\
\text { University of Technology }\end{array}$ \\
\hline
\end{tabular}

\subsection{Bivariate Analysis (Frequency Ratio)}

Bivariate statistical analysis (BSA) was used to measure landslide occurrence in each class of independent variables using frequency ratio (FR) model. Frequency ratio method illustrates the ratio of probability of the presence and the absence of any occurrence[12,13\& 20]. The greater the 


\section{Landslide Hazard Zonation From A Gis Perspective And Urban Planning Solutions In Central -Division Of Fiji Islands}

bivariate relationship (greater than 1) was the strong the relationship between the landslides and the conditioning factors. The below Eq. 1 was used to calculate frequency ratio for this present study was derived from Youssef et al [21] and Jana et al [13];

$$
W_{i j}=\frac{F L_{i i}}{F N_{i j}}
$$

where, Wij is the frequency ratio of class $i$ of parameter $j$; FLij is the frequency of observed landslide in class $i$ of parameter $\mathrm{j}$ in percent; and FNij is the frequency of nonobserved landslide in class $\mathrm{i}$ of parameter $\mathrm{j}$ in percent. Finally, to calculate the landslide susceptibility index (LSI), each factor's FR values were summed. The FSI was determined by sum of each factor's FR following Eq. 2:

$$
\stackrel{n}{\mathrm{LSI}}=\underset{j=1}{\sum \mathbf{W}_{\mathrm{ij}}}
$$

where, LSI is landslide susceptibility index; Wij is weight of class $€$ in parameter $\mathrm{j}$; and $\mathrm{n}$ is number of parameters [12].Table 3 below recorded the eight (8) parameters used for this present study.

Table 3. Parameters used through FRV model

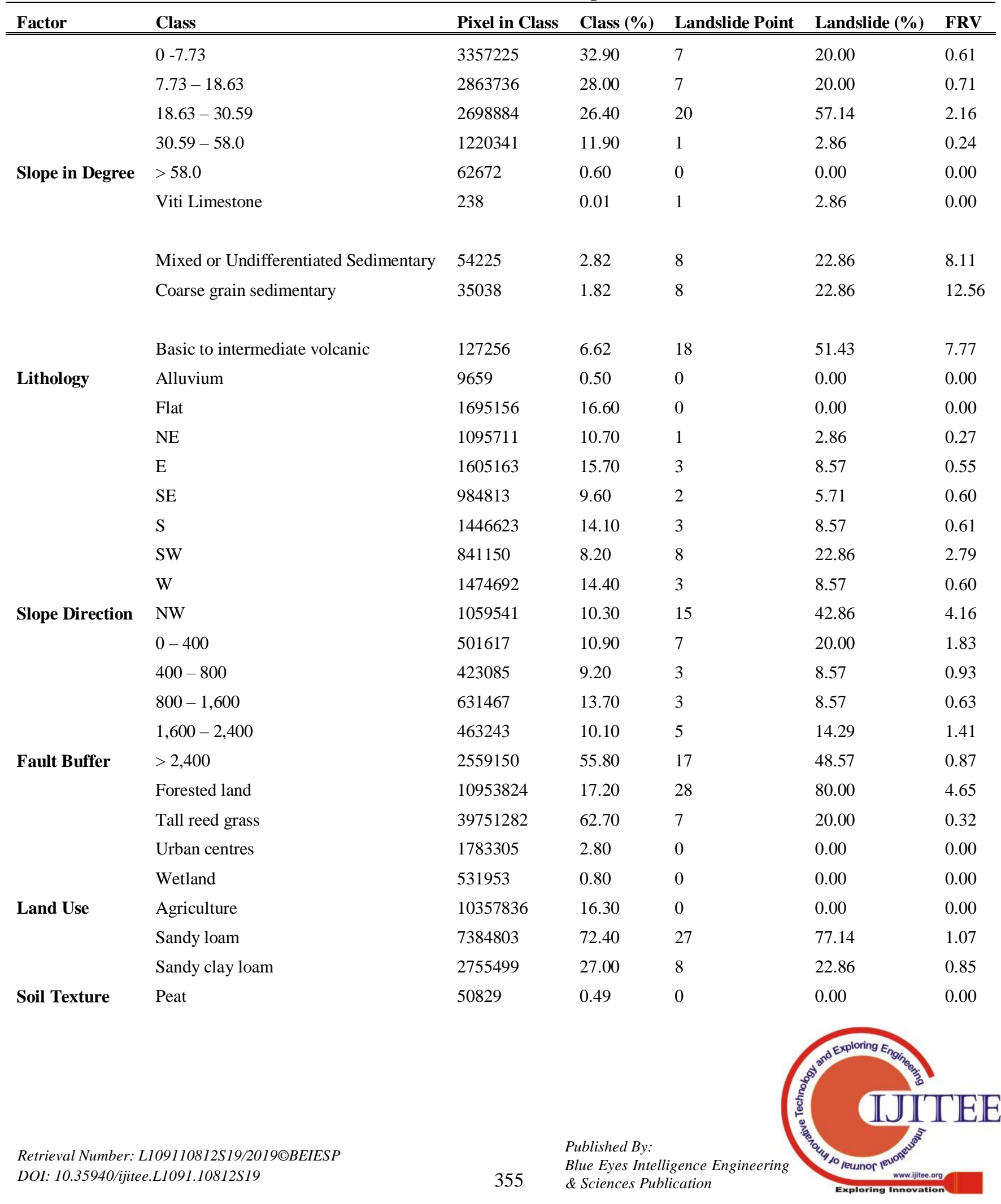




\begin{tabular}{|c|c|c|c|c|c|c|}
\hline & $0-400$ & 797904 & 17.40 & 5 & 14.29 & 0.82 \\
\hline & $400-800$ & 642311 & 14.00 & 4 & 11.43 & 0.82 \\
\hline & $800-1,600$ & 1082479 & 23.60 & 7 & 20.00 & 0.85 \\
\hline & $1,600-2,400$ & 844059 & 18.40 & 9 & 25.71 & 1.40 \\
\hline \multirow[t]{5}{*}{ Distance from River (m) } & $>2,400$ & 1211809 & 2.64 & 10 & 28.57 & 1.08 \\
\hline & $219.60-254.14$ & 2796176 & 36.2 & 9 & 25.71 & 0.07 \\
\hline & $254.14-278.32$ & 2263618 & 32.3 & 12 & 34.29 & 0.11 \\
\hline & $278.32-303.36$ & 3818406 & 13.26 & 11 & 31.43 & 0.24 \\
\hline & $303.36-350.86$ & 1047735 & 11.91 & 3 & 8.57 & 0.07 \\
\hline Rainfall (mm) & $>350.86$ & 200137 & 1.0 & 0 & 0.00 & 0.00 \\
\hline
\end{tabular}

\section{RESULTS AND DISCUSSION}

In order to provide a dynamic and vibrant realistic result, there is a need to dissect the eight (8) thematic layers used for this present study.

\subsection{Land use}

Land use reflects the feasibility of the ground to accommodate certain activities in urban and rural areas. There are five (5) classes of land use such as agriculture, forested land, tall reed grass, urban centres and wetland derived from the Fiji Ministry of Agriculture[22] and Department of Town and Country Planning [23].Figure 3aillustrates the land use distribution andFigure4aillustrates the Frequency of landslides over each class. Notably, forested land has 4.65 , tall reed grass has 0.32 whereby agriculture, urban centres and wetland has 0.0001. In urban areas, development guidelines and standards are strictly followed in order to maintain uniformity and order by local governments. Rural areas were non - monitored which results in unsustainable land use practices such as deforestation in forested land and overgrazing in tall reed grass land in particular.Moreover, agriculture, urban centres and wetland areas are situated on flat plain which establishes and prevents slides for these land uses.

\subsection{Soil Texture}

Soil texture is an essential factor determining the compaction of soil. The Ministry of Agriculture [22]differentiates three (3) soil texture categories which were sandy loam, sandy clay loam and peat. Figure $3 b$ illustrates the distribution and Figure $4 \mathrm{~b}$ reveals the frequency ratio accordingly. Sandy loam is $>1$ and has 1.07 , sandy clay loam has 0.85 and peat has 0.0001 . The relationship of landslides is high on soil with sandy loam texture basically because of its high porosity level than the other two textures. On the other hand, infiltration rate of storm water is high on sandy loam soil which makes it slippery and easy to disaggregates. Thus, sandy loam texture is looser than peat soil texture.

\subsection{Slope in degree}

Slope in degree a controlling factor which determines the pace of landslides. Steeper slopes move landmass faster than landmass on gentle slopes.In addition, landslides occur on steeper slopes whereby flows occur on river banks of flat land. Slope in degrees been classified into five (5) categories; 0 -7.73, 7.73 - 18.63, 18.63 - 30.59, $30.59-$ 58.0 and > 58.0. Slope in degrees 18.63 - 30.59 has frequency ratio value of 2.16 which is the highest and slope in degrees > 58.0 recorded the lowest which is 0.0001 . Figure $3 \mathrm{c}$ illustrates the area coverage distribution while Figure 4c illustratesthe FRV.

\subsection{River distance}

Considering the distance from water ways and rivers, there were five (5) classes of distance established in meters; $0-400,400-800,800-1,600,1,600-2,400,>2,400$. The rationale is that river banks have greater tendency to flows and decreases further towards inland. Figure $3 \mathrm{~d}$ illustrates the area coverage distribution and Figure $4 d$ illustrates the FRV. This present study reveals that distance within $0-400$ meters recorded FRV of 0.82 while distance between 1,600 $-2,400$ meters recorded FRV of 1.40 accordingly. 

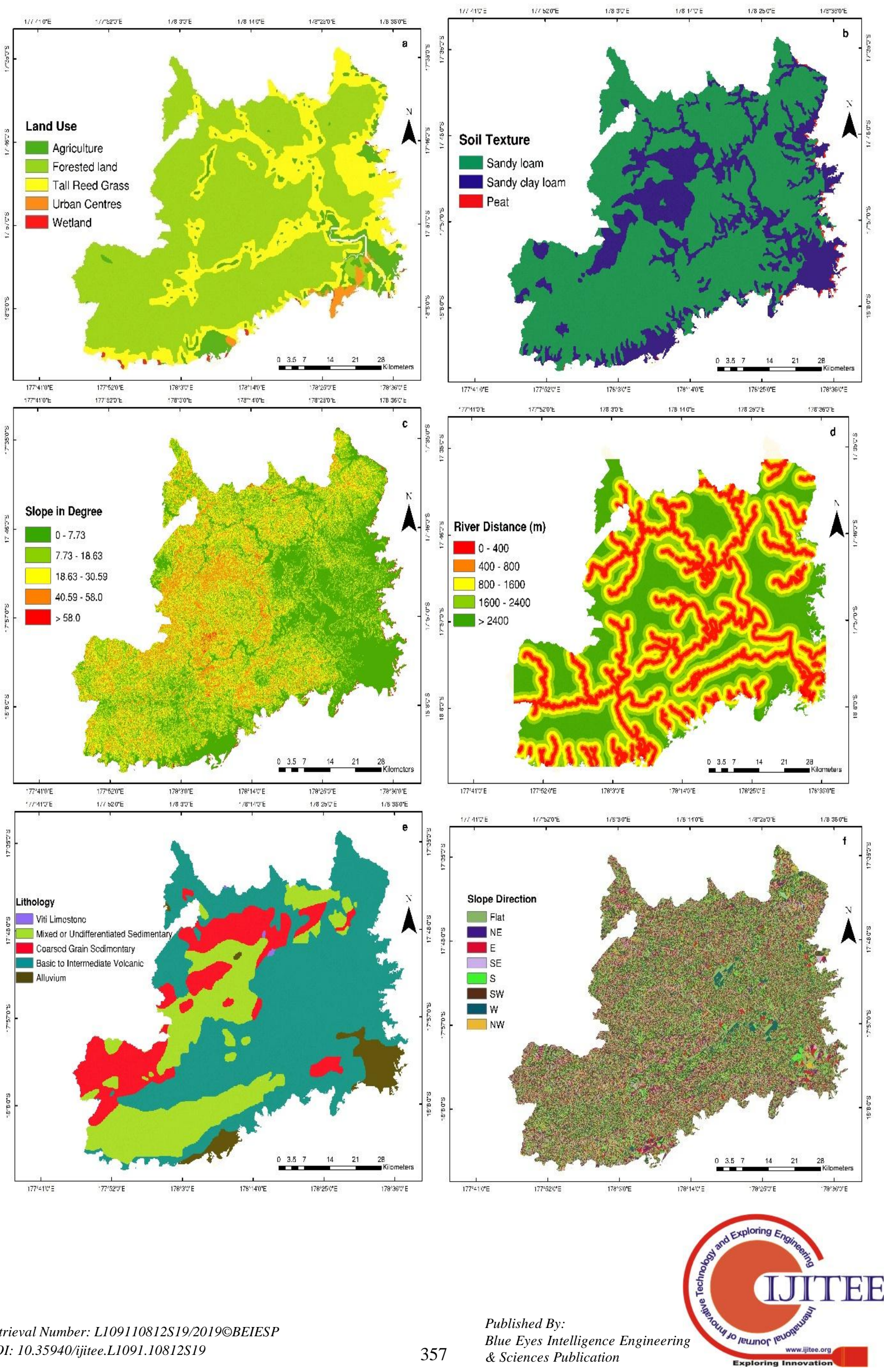

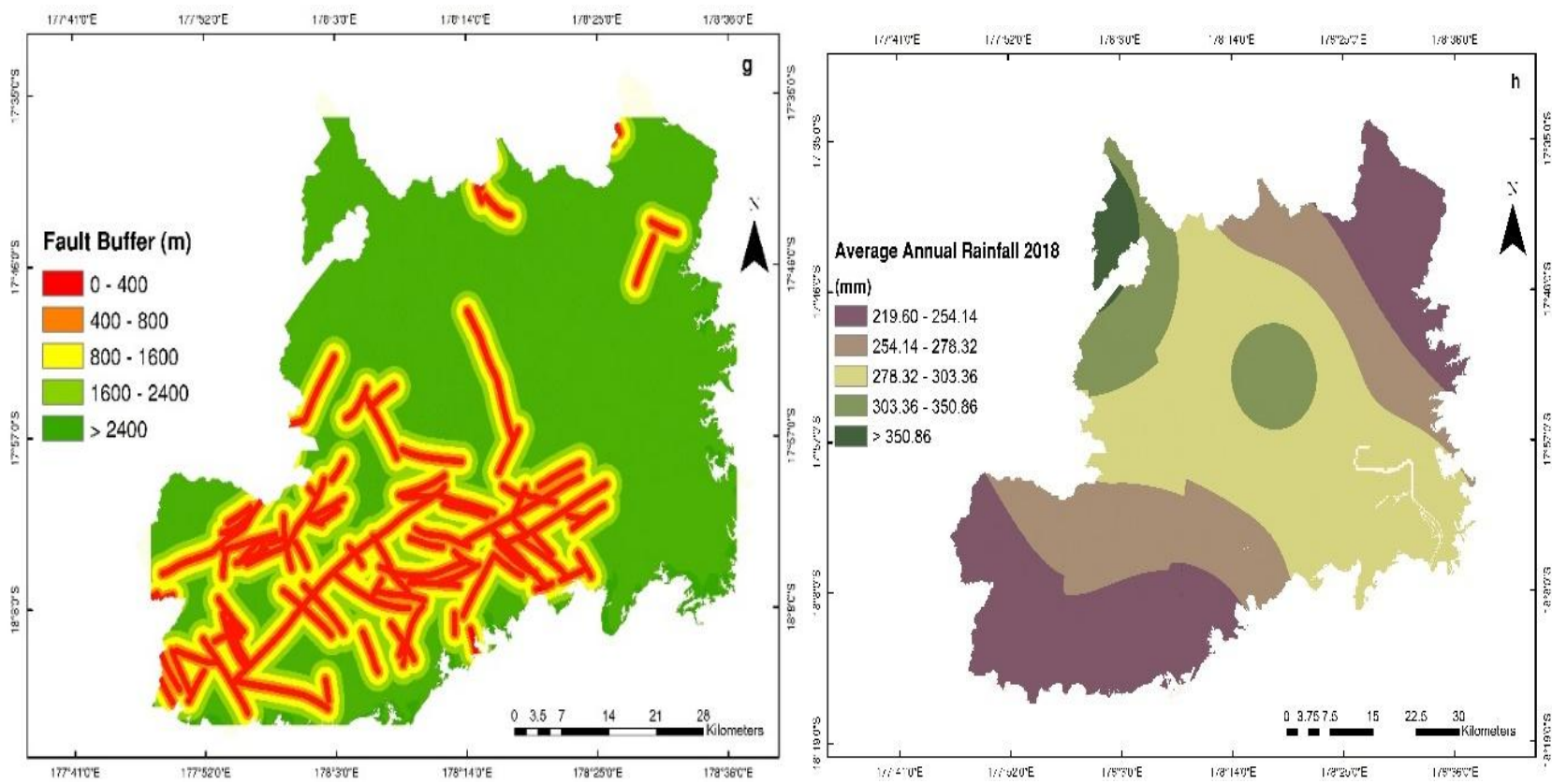

Figure 3. a Land use, bSoil texture, cSlope in degree, dRiver distance,e Lithology, f Slope direction, g Fault buffer, and $h$ Average annual rainfall 2018.

\subsection{Lithology}

Lithology plays a potent role in stabilization of soil, natural ground cover and man-made features. The five (5) classes were established according to the Fiji Mineral Resources Department [4], Rodda [24-27] and New Zealand Soil Bureau [28]geological classifications. These classes were viti limestone, mixed or undifferentiated sedimentary, coarse grain sedimentary, basic to intermediate volcanic and alluvial. This present study revealed that coarse grain sedimentary recorded FRV of 12.5 while viti limestone recorded a lowest of 0.0001 FRV.Figure 3e illustrates the area coverage while Figure 4eillustrates the FRV graphical relationship to landslides.

\subsection{Slope direction (Aspect)}

Slope direction is a potent factor to consider due to the orientation of slope to Fiji's prevailing southeast trade winds. Hence, the eight (8) directions were flat, north east $(\mathrm{NE})$, east $(\mathrm{E})$, south east (SE), south(S), south west (SW), west $(\mathrm{W})$ and north west $(\mathrm{NW})$. The study revealed that northwest direction dominated the FRV of 4.16 while flat land recorded the lowest FRV of 0.0001. The reason was the southeast trade wind brushes over vegetations on the northwest direction of the slope leaving landmass exposed to slides and falls of rocks. Figure $3 f$ illustrates the area coverage while Figure $4 \mathrm{f}$ illustrates the graphical FRV accordingly.

\subsection{Fault buffer}

Fault lines are prerequisite to landslides and sometimes titanically produced faults inseparably. Fault lines meter buffer were classified into five (5) distances which were; 0 $400,400-800,800-1,600,1,600-2,400$ and $>2,400$. This study revealed that $0-400$ meter buffer recorded the highest FRV of 1.83 while the relationship of landslides weakens further away from the fault lines. Figure $3 g$ illustrates the area coverage while figure $4 \mathrm{~g}$ illustrates the FRV.

\subsection{Rainfall}

Rainfall induced landslides are popular in Fiji Islands [6]. Rainfall readings in millimetres were classified into five (5) classes which were; 219.60- 254.14, 254.14 - 278.32, 278.32 - 303.36, 303.36 - 350.86 and > 350.86. This present study revealed that $278.32-303.36$ recorded highest FRV of 0.24 while $>350.86$ recorded the lowest. Figure $3 g$ illustrates the area coverage while Figure $4 \mathrm{~g}$ illustrates the graphical relationship of FRV.

(a)

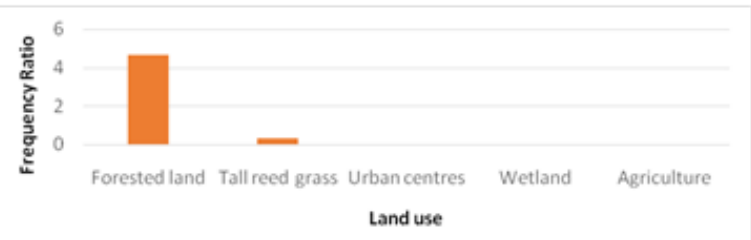

(b)

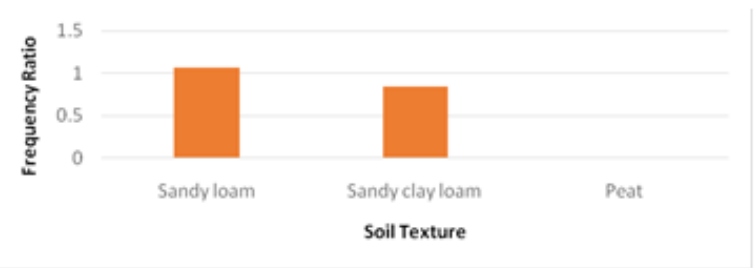

(c)

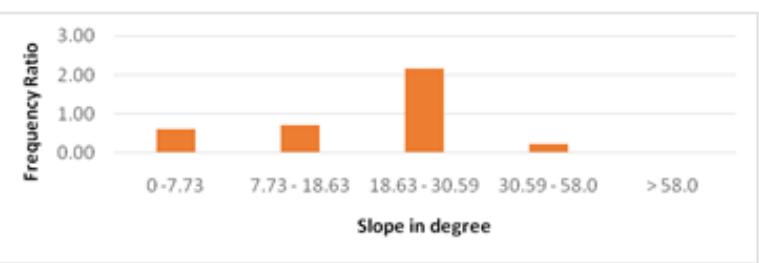

Published By: 
(d)

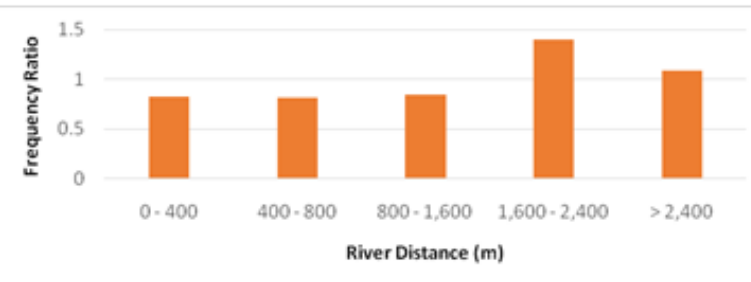

(e)

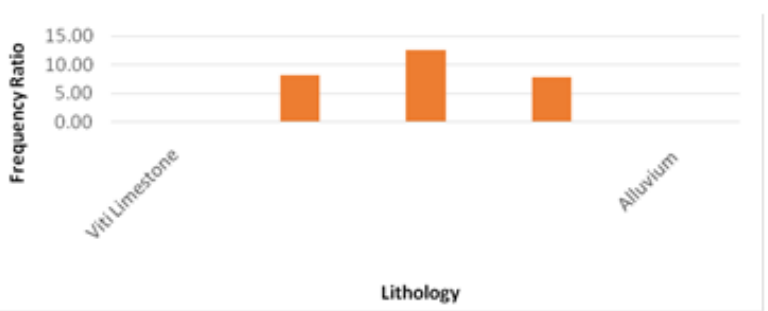

(f)

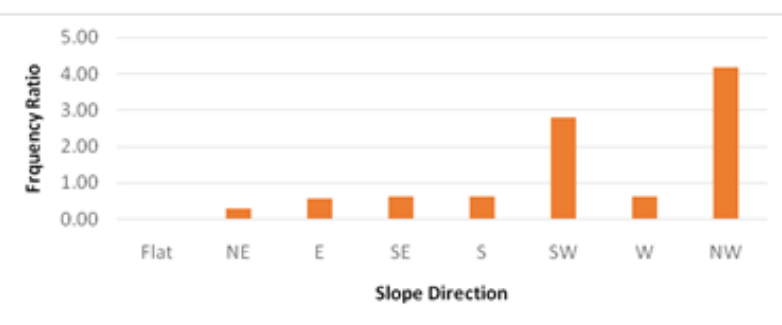

(g)

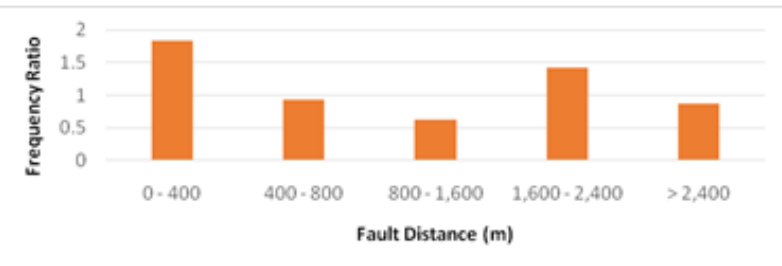

(h)

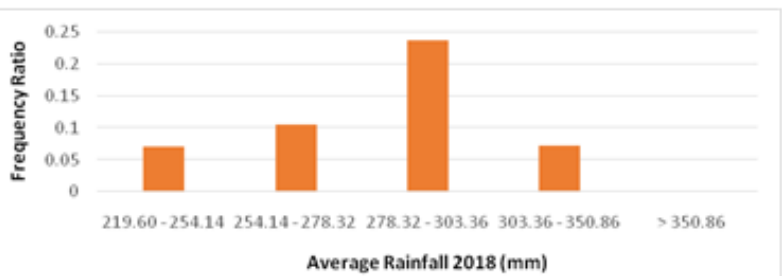

Figure 4. Factors' classes against Frequency Ratio Value (FRV); a Land use, bSoil Texture, cSlope in degree, dRiver distance,eSlope direction, $f$ Lithology, $g$ Fault distance, and $h$ Average annual rainfall 2018

\subsection{Landslide susceptibility zonation}

The final landslide vulnerability zonation on central district was derived using the formula mentioned earlier in Eq. 2 which sums the eight parameters were reclassified and resampled into $20 \times 20$-meter pixel size using the multi criteria analysis in ArcGIS 10.5 software. Figure 5 illustrates the area coverage distribution of the five (3) zones from 'low, moderate, high'.

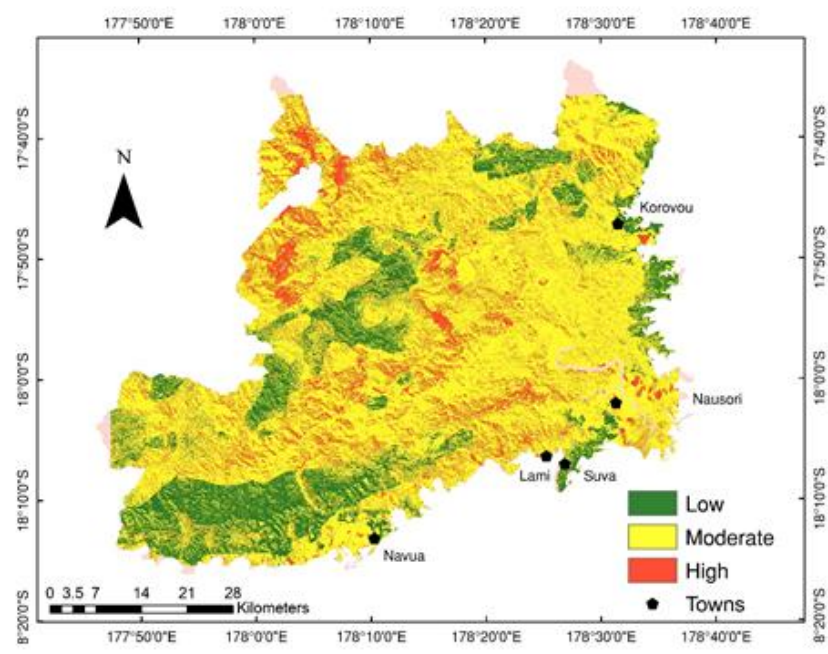

Figure 5. Final landslide frequency zonation of the central division in Fiji Islands.

Interesting to note that the areas associated with high rainfall has more risks to landslides, falls and flows which evidently shown in the central eastern part of the study area. Table 4 below illustrates the five (5) classifications and the area coverage whereby Figure 6 graphically illustrates the distribution. According to 2017 population census, approximately $38.7 \%$ of Fiji's total population dwells within the study area alone[3]. The records of socio - economic related issues such as crime, informal urbanism and unemployment were relatively high. Man-made developments such as construction of apartments and shopping malls, road maintenance and housing are increasingly evident of thriving economic activities in the study area.

Table 4. Results of landslide susceptibility zone and percentage area

\begin{tabular}{llllr}
\hline $\begin{array}{l}\text { Landslide } \\
\text { Susceptibility } \\
\text { Index }\end{array}$ & $\begin{array}{l}\text { Landslide } \\
\text { susceptibility } \\
\text { class }\end{array}$ & $\begin{array}{l}\text { Occurrence } \\
(\%)\end{array}$ & $\begin{array}{l}\text { Area of } \\
\text { susceptibility } \\
\text { class }\left(\mathrm{km}^{2}\right)\end{array}$ & $\begin{array}{l}\text { \% area of each } \\
\text { susceptibility }\end{array}$ \\
\hline \hline $0.1-1.2$ & Low & 20 & 660 & 16.62 \\
$1.2-2.1$ & moderate & 26 & 2720 & 68.51 \\
$2.1-3.0$ & High & 54 & 590 & 14.86 \\
\hline
\end{tabular}

The study revealed the following; low covers $660 \mathrm{~km} 2$, moderate covers $2720 \mathrm{~km} 2$, and high covers $590 \mathrm{~km} 2$ Figure 6 illustrates thatmoderate zone covers more area than the four zones accordingly.

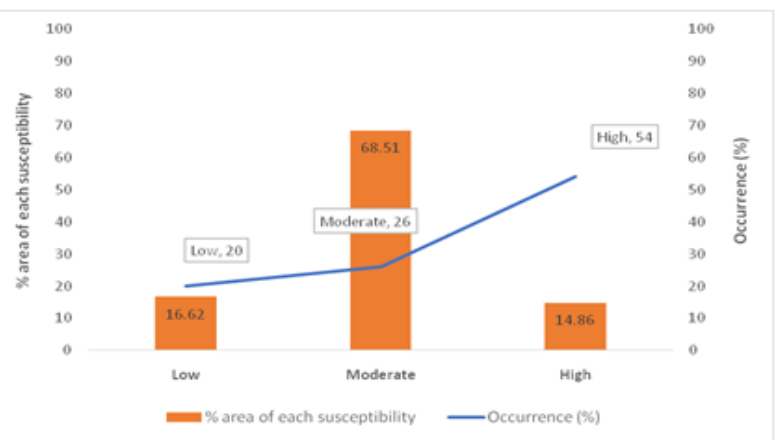

Figure 6. Final landslide frequency zonation distribution.

Published By 
In lieu, there were several limitations to this present study such as budget and time constraints. However, the ultimate aim is to identify areas of high risks and inform all levels of government of their vulnerabilities and take actions accordingly. Urban and regional planners should be made aware and eloquent with landslide locations in order to formulate guidelines, policies and regulations to reduce spiral socio-economic, natural and physical risks attached to a target population. Local governments within the central division namely Suva City Council (SCC), Lami Town Council (LTC), Nasinu Town Council (NTC), Nausori Town Council (NTC) and Navua Rural Authority (NRA) need to encapsulate disaster prone areas into their local town scheme.

\section{VALIDATION OF RESULTS}

The result was validated based on the landslide susceptibility index and landslide occurrence using the ArcGIS 10.5 software. The graph in Figure 7 illustrates the relationship and the Area Under Curve (AUC) was calculated accordingly. The AUC curve was calculated to be 0.86 or $86 \%$ which is acceptable. Hence, the landslide zones were adopted and accepted to be the true reflection of landslides area. This AUC curve does not predict future landslides but validated the landslides areas of this present study. Thus, the landslides occurrence data points were also inserted in line with the confusion matrix technique which eliminates the bias or random components accordingly.

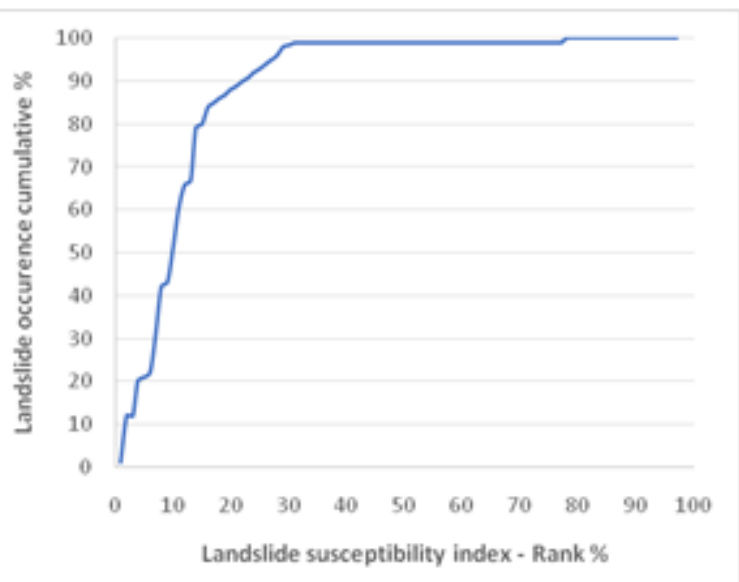

Figure 7. Landslide susceptibility validation curve

\section{CONCLUSION AND RECOMMENDATIONS}

Landslidesare lethal to humanity and costly to mad-made structures when occurred. However, humanity has been equipped with intellect to design preventative measures in order to reduce the risks of landslides. Using frequency ratio methodology is provedaffordable, reliable and accurate to delineate hazard zones especially for Fiji Islands. With limited technological resources, it was impetus to improvise whatever available information or data with GIS and RS knowledge gained so far to produce a landslide hazard zonation for the central division. The following recommendations were re-emphasizedby Mycoo[29] \&Wainiqolo[30]; 1) mainstreaming disaster planning into local town planning scheme - planners are either ignorant or lack understanding on types of natural disaster surrounding their designated town boundary., 2) mainstreaming technology into planning - the current effort of digitizing plans and converting hard copy into soft copy are appreciated but planners need to identify areas of high risks in order to pre-mobilize resources to accommodate people during disaster events., 3) mainstreaming public participation - the current practices of planning for the people are appreciated but people need to plan for themselves in the presence of planners through consultation, awareness and workshops. Traditional and local knowledge are paramount which needs to be taken into consideration. Moreover, people will take ownership of local plans and conform the rules and regulations that they designed. In other words, empowering local communities to implement soft measures such as sustainable farming practices in rural areas, proper hillside and coastal developments and protection of watershed areas. While in urban areas, developers will conform to the development standards and guidelines such as developable floor area ratio and building heights. Finally, the following tool kits are present with the planners but they need to optimize the use thereof;Town Planning Schemes, Local Area Plans, and Regional Plans., development Control Regulation - TP Act General Provisions., Legislation - TCP Act, Subdivision of Lands Act., Smart Growth Initiatives/Policies., Moratoriums., Public Participation and Stakeholder Consultation., GIS Mapping and Remote Sensing., Environment Impact Assessment Reports., Vulnerability/Hazard Maps., Village Planning and Partnership with Local Governments.

\section{ACKNOWLEDGEMENT}

This paper would not be possible without the assistance, support and dedication of the following institutions. Firstly, Fijigovernmental ministries/departments namely Fiji Meteorology Department, Fiji Mineral Resources Department, Fiji Town and Country Planning Department Fiji Bureau of Statistics and Ministry of Agriculture. Secondly, the European Union for financing this post graduate programme. Thirdly, the Papua New Guinea University of Technology for hosting this research and allowing access to their laboratory. Fourthly, the co-authors for their willingness to share gigantic knowledge for the betterment of the research community and Fiji as a whole. Last but not the least, we thank all the reviewers for their meticulous observation, constructive remarks and informative comments which qualifies the publication of this manuscript.

\section{REFERENCES}

1. Mycoo, M. A. (2014). "Autonomous Household Responses and Urban Governance Capacity Building for Climate Change Adaptation: Georgetown, Guyana." Urban Climate9: 134-154

2. Wade, B., and D, Webber. (2002). "Coastal Zone Management. Natural Resources Management for Sustainable Development in the Caribbean: 427-81. 
3. Fiji Bureau of Statistic. (2017). Population census by province. Retrieved from http://www.statsfiji.gov.fj/

4. Fiji Mineral Resources Department. (2015). Plate Tectonic History of Fiji. Suva, Fiji Islands.

5. Bartholomew, R. W. (1959). Geology of the Lautoka area, North-West Viti Levu. Bull. geol. Surv. Dep. Fiji.

6. Greenbaum, D., Bowker, M.R., Dau, I., Dropsy, H., Greally, K.B., Donald, A., Marsh, H., Northmore, J., O'connor, A., Prasad, S., Tragheim, G., (1995). Rapid methods of landslide hazard mapping: Fiji case study. Technical report WC/95/28 overseas geology series. British geological survey.

7. Westen, C. J. V., Rengers, N., Terlien, M. T. J., \&Soeters, R. (1997). Prediction of the occurrence of slope instability phenomena through GIS-based hazard zonation. GeologischeRundschau, 86, 404-414.

8. Deng, X., Li, L., \&Yufang, T. (2017). Validation of spatial prediction models for landslide susceptibility mapping by considering structural similarity. International Journal of Geo-Information, ISPRS, 6, 103. https://doi.org/10.3390/ijgi6040103.

9. Solaimani, K., Mousavi, S. Z., \&Kavian, A. (2013). Landslide susceptibility mapping based on frequency ratio and logistic regression models. Arabian Journal of Geosciences, 6, 2557-2569. https://doi.org/10.1007/s12517-012-0526-5.

10. Lee, S., \& Pradhan, B. (2007). Landslide hazard mapping at Selangor, Malaysia using frequency ratio and logistic regression models. Landslides, 4, 33-41. https://doi.org/10.1007/s10346006-0047-y.

11. Park, S., Choi, C., Kim, B., \& Kim, J. (2013). Landslide susceptibility mapping using frequency ratio, analytic hierarchy process, logistic regression, and arti?cial neural network methods at the Inje area, Korea. Environmental Earth Sciences, 68, 1443-1464. https://doi.org/10.1007/s12665-012-1842-5.

12. Samanta, S., Pal, D. K., \&Palsamanta, B. (2018). Flood susceptibility analysis through remote sensing, GIS and frequency ratio model. Applied Water Science, 8, 66. https://doi.org/10. 1007/s13201-018-0710-1.

13. Jana, S.K., Sekac, T., \& Pal, D.K. (2019). Geo-spatial approach with frequency ratio method in landslide susceptibility mapping in the Busu river catchment, Papua New Guinea. Spatial Information Research, 27(1), $49-62$.

14. Lawson, T. 1993. South east Viti Levu landslide project preliminary study. Fiji Mineral Resources Department, MRD Note BP59/2, 76p.

15. Howorth, R., Crozier, M. J., \& Grant, I. J. (1981). Effects of Tropical Cyclone Wally in Southeast Viti Levu, Fiji, Easter 1980. Search, 12(1/2).

16. Ram, A. R., Brook, M. S., \& Cronin, S. J. (1981). Engineering geomorphological investigation of the Kasavu landslide, Viti Levu, Fiji. Landslides, 1-11.

17. Greenbaum, D., Bowker, M. R., Dau, I., Dropsy, H., Greally, K. B., McDonald, A., \&Tragheim, D. G. (1995). Rapid methods of landslide hazard mapping: Fiji case study.

18. Varo, J., Sekac, T., Jana, S.K., \& Pal, D. K. (2019). Demarcation of liquefaction potential zones and risks reduction in Fiji Islands from a geomatic perspective: a case study of Viti Levu island. Spatial Information Research, 1-16.

19. Ram, A. R., Brook, M. S., \& Cronin, S. J. (2018). Geomorphological characteristics of slope failures in northeast Viti Levu island, Fiji, triggered by Tropical Cyclone Winston in February 2016. New Zealand Geographer, 74(2), 64-76.

20. Pradhan B, \& Lee S. (2010). Delineation of landslide hazard areas on Penang Island, Malaysia, by using frequency ratio, logistic regression, and artificial neural network models. Environ Earth Sci 60:1037-1054

21. Youssef AM, Pradhan B, Sefry SA (2016). Flash flood susceptibility assessment in Jeddah city (Kingdom of Saudi Arabia) using bivariate and multivariate statistical models. Environ Earth Sci 75:12 (1-16) https ://doi.org/10.1007/s1266 5-015-4830-8

22. Fiji Ministry of Agriculture Land Classification Guideline. (2015). Land Use Guideline. https://pafpnet.spc.int/pafpnet/attachments/article/183/La nd\%20Use\%20Capability\%20Guideline_web.pdf

23. Fiji Department of Town and Country Planning. (2018) Town Planning Schemes. Fiji Islands.

24. Rodda, P. (1966). Geology of Viti Levu. Geol. Surv. Fiii, Map G.S. 432.

25. Rodda, P. (1967). Geology of Viti Levu. Geol. Surv. Dep. Fiji, A. Rep. (for 1966): 8-16.

26. Rodda, P. (1974). Fiji. Geological Society, London, Special Publications, 4(1), 425-431. doi:10.1144/gsl.sp.2005.004.01.25

27. Rodda, P. (1984). Stratigraphic names in Fiji - revision of spelling (Note). New Zealand Journal of Geology and $\begin{array}{lll}\text { Geophysics, } & 27(1), & 97-98 .\end{array}$ doi:10.1080/00288306.1984.10422292

28. New Zealand Soil Bureau. (1960). Report on the Soil Resources of Fiji. Geological Map of Fiji. Department of Scientific and Industrial Research. New Zealand

29. Mycoo, M. (2014). Sustainable tourism, climate change and sea level rise adaptation policies in Barbados. Natural Resources Forum

30. Wainiqolo, D. (2015). A physical planning perspective of integrated planning and management in the Fiji Islands. Thesis. Fiji Islands. 